\title{
O LUGAR DA INTERPELAÇÃO ÉTICA: O COLÓQUIO DUSSEL/VELASCO
}

\author{
Claudinei Aparecido de Freitas da Silva ${ }^{1}$
}

\begin{abstract}
Resumo:
O texto retoma um debate ainda em curso acerca do estatuto último da interpelação ética no contexto de uma filosofia da libertação aberta por Dussel e reorientada criticamente por Sirio Lopez Velasco. Para tanto, a análise se centrará no modelo velasquiano de uma "ética argumentativa" fundada à luz de três normas transcendentais tendo na perspectiva do "ecomunitarismo" seu horizonte utópico, por excelência.
\end{abstract}

Palavras-chave: Enrique Dussel. Ética. Interpelação. Sirio Lopez Velasco. Ecomunitarismo.

\section{THE PLACE OF ETHICAL INTERPELLATION: THE DUSSEL/VELASCO COLLOQUY}

\begin{abstract}
:
The text takes in a still ongoing debate about the ultimate statute of ethical interpellation in the context of a liberation philosophy opened by Dussel and critically reoriented by Sirio Lopez Velasco. To do so, the analysis will focus on the Velasquian model of an "argumentative ethics" founded in the light of three transcendental norms having in perspective of "ecomunitarism" its utopian horizon, par excellence.
\end{abstract}

Keywords: Enrique Dussel. Ethics. Interpellation. Sirio Lopez Velasco. Ecomunitarism.

A Sirio Lopez Velasco

Professor dos Cursos de Graduação e de Pós-Graduação (Stricto Sensu) em Filosofia da UNIOESTE Campus Toledo com Estágio Pós-Doutoral pela Université Paris 1 - Panthéon-Sorbonne (2011/2012). Escreveu "A carnalidade da reflexão: ipseidade e alteridade em Merleau-Ponty" (São Leopoldo, RS, Nova Harmonia, 2009) e "A natureza primordial: Merleau-Ponty e o logos do mundo estético"” (Cascavel, PR, Edunioeste, 2010). Organizou "Encarnação e transcendência: Gabriel Marcel, 40 anos depois" (Cascavel, PR, Edunioeste, 2013), "Merleau-Ponty em Florianópolis" (Porto Alegre, FI, 2015), "Kurt Goldstein: psiquiatria e fenomenologia" (Cascavel, PR, Edunioeste, 2015), Festschrift aos 20 anos do Simpósio de Filosofia Moderna e Contemporânea da UNIOESTE (Cascavel, PR, Edunioeste, 2016) e, em parceria com Franco Riva, Compêndio Gabriel Marcel (Cascavel, PR/Goiânia: Edunioeste/Editora PUC Goiás, 2017). E-mail: cafsilva@uol.com.br. 


\section{Estado de questão}

A exposição que se segue visa demarcar, em suas linhas gerais, uma pauta cuja agenda remonta pouco mais de trinta anos de colóquio. Trata-se de reconstituir, minimamente, o vetor teórico da categoria de "libertação" em sua chave interpretativa mais eloquente e decisiva protagonizada, a nosso ver, pelas obras de Enrique Dussel e Sirio Lopez Velasco. É propriamente esse conceito emblemático que nas mãos de ambos os autores assume ora uma leitura convergente, ora divergente programaticamente. Por uma parte, a convergência se dá quanto à necessidade de se vislumbrar outro horizonte emancipatório (utópico) de resistência e luta como orientação pós-colonialista e póscapitalista de libertação, desde a América Latina. Por outra, a divergência de fundo quanto à estratégia teórico-prática dessa emancipação. O que o leitor tem, em primeira mão, são duas formulações originais em que ambos os pensadores se dedicam a refletir, mais profundamente, o lugar da interpelação do Outro enquanto Outro cujo rosto é eticamente negado em sua exterioridade última e carnal.

Para então acalorar o debate, partamos do primeiro lugar de interpelação ética: o programa dusseliano de uma filosofia da libertação e sua perspectiva profética do Outro como rosto.

\section{Interpelação ética I: Dussel e a libertação profética do rosto}

Em seu pioneiro e célebre estudo, Filosofia da Libertação na América Latina, Dussel ensaia algumas premissas programáticas. Ele, então, argumenta:

\footnotetext{
A proximidade metafísica se realiza inequivocamente, realmente, diante do rosto do oprimido, do pobre, daquele que, exterior a todo sistema, clama justiça, provoca a liberdade, invoca responsabilidade. A proximidade inequívoca é a que se estabelece com aquele que precisa de serviço, porque é fraco, miserável, necessitado (Dussel, 1982, p. 26).
}

Retrata ainda Dussel (1982, p. 47) que "o rosto do homem que se revela como outro [...] não é algo; é alguém”. Esse “alguém” cujo rosto clama por justiça se revela, antes

\begin{tabular}{|l|l|l|l|l|}
\hline Q Povista Dialectus & Ano 5 & n.13 & Agosto - Dezembro 2018 & p. $100-115$ \\
\hline
\end{tabular}


de tudo, como "pessoa, como provocação e juízo por sua simples revelação" (Dussel, 1982, p. 49). Ele é, enfim, esse "outro como rosto interpelante, revelante, provocante" (Dussel, 1982, p. 50). O outro é esse “juízo" que "provoca” como "alguém” que invoca responsabilidade e, portanto, carece de serviço: caso contrário, seria uma simples coisa ou objeto sem qualquer apelo ou clamor de justiça. Dussel, sem dúvida, situa essa interpelação à luz de um certo eco levinasiano cujo fundo acústico é, seguramente, Totalité et infini (2006). É verdade, admite ele, que a ética deve explicitar de que "mais além" da totalidade se situa o outro, algo que Levinas mostrou bem "a partir da fenomenologia, mas não a partir da economia política” (Dussel, 1987, p. 261). É sob esse escopo preferencial, mas não exclusivo, que Dussel quer pensar com e para além de Levinas. É preciso, pois, reconhecer o outro para além de sua manifestação puramente fenomênica ${ }^{2}$. Esta é uma formulação profunda, não há a menor dúvida, mas ainda insatisfatória, já que se mostra "abstrata" (Dussel, 1982, p. 190) e universalista. Ora, Dussel localiza justamente esse déficit da ética levinasiana para, enfim, agregar em sua concepção uma teoria da produção anticolonialista ou anticapitalista crítico-libertadora desde também um espaço geopolítico privilegiado. Trata-se de uma teoria que seja capaz de reconhecer "o povo em movimento", quer dizer, “descobrir o novo, o outro, aquele que interpela como um sempre além e que só fala àquele que tem o ouvido adestrado: ao que pensa desde a opressão para que nasça a fillosofia na América Latina” (Dussel, 1982, p. 193). Por essas palavras, Dussel situa o lócus originário desde onde essa interpelação filosoficamente se institui: não mais a partir de um "centro norte-atlântico", eurocêntrico, mas da "periferia", de um "terceiro mundo" assolado pelo imperialismo do "primeiro".

Por isso, nossa filosofia da libertação fixará sua atenção no passado do mundo e na espacialidade, para detectar a origem, a arqueologia de nossa dependência, debilidade, sofrimento, aparente incapacidade, atraso (Dussel, 1982, p. 31).

\footnotetext{
${ }^{2}$ Dussel (1982, p. 64), p. ex., avalia que "a ontologia é fenomenologia; é o lógos ou pensamento acerca daquilo que aparece (o fenômeno, o ente) desde o fundamento (o ser)". Por isso, para além de Levinas e toda a tradição fenomenológica, "a libertação não é uma ação fenomênica, intra-sistêmica; a libertação é a práxis que subverte a ordem fenomenológica e a transpassa numa transcendência metafísica que é a crítica total do estabelecido, fixo, normalizado, cristalizado, morto" (Ibidem).
}

\begin{tabular}{|l|l|l|l|l|}
\hline Qenista Dialectus & Ano 5 & n.13 & Agosto - Dezembro 2018 & p. $100-115$ \\
\hline
\end{tabular}


O que esse lugar originário da interpelação evidencia é que "o rosto do outro, primeiramente como pobre e oprimido, revela realmente um povo, mais do que a mera pessoa singular" (Dussel, 1982, p. 50). Nesse âmbito, a noção de rosto se amplifica consideravelmente já que transcende a singularidade de alguém, pura e simples, ou seja, o rosto assume inúmeras figurações que vão desde, p. ex., a identidade de gênero, classe social, cultura ou etnia. Esse traço é importante no contexto aqui teoricamente presumido, uma vez que o autor põe em cena um novo rosto (não apenas singular, mas plural) à luz de uma reflexão verdadeiramente libertadora: “o rosto (prósopon, em grego, persona) do pobre, sua corporalidade; é ela mesma, a palavra originária de onde parte a filosofia da libertação que não pensa palavras, mas realidade" (Dussel, 1982, p. 249).

No entanto, essa realidade que parece urgir mais que simples palavras já que interpela como a palavra originária por excelência, assume outros aspectos semânticos. Dussel entende que "o 'rosto' indica o que aparece do outro, de sua corporalidade, de sua realidade "carnal"' (Dussel, 1987, p. 19), mas o "pobre não apenas sofre em sua carnalidade, em sua sensibilidade, a falta de bens materiais de consumo. Sofre também a falta de outros bens" (Dussel, 1987, p. 79). Quer dizer, o sentido dusseliano do rosto se projeta além também da economia política. É que o sofrimento do pobre exprime outra carência que transcende as condições materiais de existência na acepção de Marx; é um sofrimento tanto carnal (material) quanto espiritual. O rosto, por expressão, também passa a se identificar, em sentido místico ou religioso. Por isso, tomado, positivamente, o oprimido enquanto "rosto" é "esse pobre aí, 'Ecce homo', suplicando por trabalho, por salário, que, em sua fome, é o próprio Cristo" (Dussel, 1987, p. 141).

Ora, é precisamente aqui, que Dussel demarca um importante índice de seu movimento reflexivo. Há um traço decididamente teológico, por princípio, nessa formulação. $\mathrm{O}$ reconhecimento do outro encontra na figura de Cristo e em sua mensagem evangélica, um lugar desde onde sua voz pode, efetivamente, ser ouvida. Dussel então planta uma baliza: "Quando o outro fala a partir de si, não pela compulsão da tortura que na desesperança o inclina a delatar, revela sua exterioridade, sua alteridade que a razão nunca poderá perscrutar desde si mesma" (Dussel, 1982, p. 52). O que isso quer dizer? Dussel sugere que essa alteridade interpelante se situa noutro horizonte; horizonte este, em rigor,

\begin{tabular}{|c|c|c|c|c|}
\hline Qovista Dialectus & Ano 5 & n.13 & Agosto - Dezembro 2018 & p. $100-115$ \\
\hline
\end{tabular}


inabarcável pela razão. O clamor de justiça do rosto do outro só se torna audível via outro critério: a fé. Ora, é esse argumento que a proposição abaixo não deixa a menor sombra de dúvida:

\begin{abstract}
Aceitar a palavra do outro porque ela o revela sem outro motivo senão porque ele a pronuncia, é a fé. O que me revela não tem outro critério de certeza a não ser a própria realidade do outro como outro. Não aceito o que me revela nem pela evidência de seu conteúdo, nem por ser certo. Aceito porque atrás de sua palavra se encontra a própria realidade de alguém, imediatamente, aberto e exposto a uma abertura metafísica em relação à qual a abertura ontológica ao mundo é uma longínqua imitação. Revelar é expor-se ao traumatismo, como aquele que abre sua camisa diante do pelotão de fuzilamento. Crer é lançar-se no vazio porque o outro afirmou que no fundo do abismo há água e não se corre perigo. Relação metafísica por excelência, proximidade, revelação, fé, racionalidade histórica suprema, humana. (Dussel, 1982, p. 52-53).
\end{abstract}

Dussel marca bem sua posição: a revelação do outro pressupõe menos um ato racional e mais uma profissão de fé $^{3}$. O éthos libertador presume essa exigência; exigência que transcende toda evidência racional como critério último de aceitabilidade. Por isso, ele escreve que "crer é lançar-se no vazio" do qual o outro é a condição última de uma interpelação irrenunciável. O outro (aqui, como povo) assume um lugar hermenêutico de primeira ordem porque também radica uma expressão sagrada de interpelação. O pobre se reconhece também como verbo que se faz carne. Nesse sentido, o clássico dito vox populis vox Dei! parece tomar aqui um valor semântico inestimável.

É assim que, a par desse registro claramente teológico, a categoria de povo assume um estatuto singular como vetor messiânico à luz do próprio texto dusseliano. Várias narrativas, de inspiração bíblica, dão o tom desse discurso à medida que o povo cujo rosto é o oprimido em suas mais variadas facetas encarna, por vezes, uma identidade profundamente religiosa ou sacral, a exemplo do "povo de Deus" guiado no deserto (desde América Latina) por inúmeros líderes (Che Guevara, Fidel, Sandino, etc) ou "Moiséis"

\footnotetext{
3 Isso tudo, muito embora, o autor milite em favor de um ateísmo, a saber, a do "antifetichismo ateu" (Dussel, 1982, p. 104ss). Quer dizer: Dussel (1982, p. 65) caracteriza "a consciência ética como a capacidade que se tem de escutar a voz do outro, palavra transontológica que irrompe de além do sistema vigente [...]. As condições de possibilidade para poder ouvir a voz do outro são muito claras [...]. Em primeiro lugar, para poder ouvir a voz do outro, é necessário que sejamos ateus do sistema ou descobrir seu fetichismo. Em segundo lugar, é necessário respeitar o outro como outro [...]. O outro é o único realmente sagrado e digno de respeito sem limite. O respeito é silêncio, mas não silêncio daquele que nada tem a dizer, e sim daquele que tem que escutar tudo, porque nada sabe do outro como outro".
}

\begin{tabular}{|l|l|l|l|l|}
\hline Q ovista Dialectus & Ano 5 & n.13 & Agosto - Dezembro 2018 & p. $100-115$ \\
\hline
\end{tabular}


(Dom Romero) $)^{4}$. A figura de um "Messias" como alguém que guia o povo se torna emblemática nesse cenário. Há um acento sempre reincidente seja na imagem do líder, seja na do profeta-mártir. Há, portanto, um culto à personalidade, à ideia de um "salvador da pátria", isto é, como referência patriótica e, portanto, libertadora ${ }^{5}$. Sob esse aspecto, demos uma vez mais a palavra a Dussel (1982, p. 83):

O político libertador é o protótipo do homem político, mais ainda se se leva em consideração que hoje, nas formações sociais periféricas a última instância é política. [...]. Seu projeto de libertação nega a negação dos oprimidos e afirma sua exterioridade. São como Moisés ou Maomé, os símbolos de um povo que nasce, que cresce, que vive. São profetas da vida e não da morte; fundadores da liberdade e não assassinos dela.

É assim também que, em suas 20 Teses de Política, Dussel ainda mantém premissas desse gênero quando, p. ex., ao parecer tomar para si o testemunho de um jovem de dezoito anos citado por Marx: "a própria religião ensina que o ideal a que todos aspiram é o de sacrificar-se pela humanidade" (Dussel, 2007, p. 113-114). Essa ideia de sacrifício se alia à do mártir como aquele que, em tal processo de libertação, exerce, de fato e de direito, uma missão profética. Como bem acena Dussel (1987, p. 104), o que temos aqui é a expressão de uma "heroicidade política" que visa cumprir cada vez mais certa "função escatológica".

Assim, o reconhecimento dessa interpelação sacral exige, mais uma vez, essa proximidade pela fé. Isso implica, vale reiterar, que toda decodificação do apelo do outro se situa "não no nível da interpretação racional, mas daquele da aceitação de seu significado porque ele o diz (é assim um ato histórico e perigoso de fé” (Dussel, 1982, p. 131). De resto, "a única maneira de decodificar adequadamente o significado pela palavra

\footnotetext{
${ }^{4}$ Em trabalhos mais recentes, conforme suas 20 Teses de Politica, Dussel identifica outras experiências contemporâneas como signos de um novo movimento libertador, desde América Latina. Ele cita, p. ex., Nestor Kirchner, Hugo Chaves, Evo Morales e Luís Inácio Lula da Silva como ícones desse estágio emancipatório "transmoderno" e "transcapitalista" (Dussel, 2007, p. 9; 10). Mais: esses atores políticos representam "os ventos que nos vêm do Sul [...] mostrando-nos que as coisas podem mudar e que o povo reassume a soberania" (2007, p. 122).

${ }^{5}$ Como é o caso também do líder político congolês: "Quando o soldado traidor estava para cravar sua baioneta no ventre de Lumumba, este exclamou: 'Tudo para a libertação do povo africano!'. Sua vida era pouco como oferenda e culto do projeto de uma pátria nova. Sua práxis suprema era sua própria morte. Seu sangue fecundo, o nascimento de uma nova África. Por isso, sua práxis subversiva era ética; seu projeto destrutivo do antigo e morto era metafísico" (Dussel, 1982, p. 83).
}

\begin{tabular}{|l|c|c|c|c|}
\hline Ronista Dialectus & Ano 5 & n.13 & Agosto - Dezembro 2018 & p. $100-115$ \\
\hline
\end{tabular}


interpelante, subversiva, é realizando uma ação prática de serviço que permite ao que recebe a mensagem $\left(M^{\prime}\right)$ aceitar realmente o âmbito de exterioridade onde se encontra o outro (R')” (Dussel, 1982, p. 131). Desse modo, “o outro se revela (parousia) apocalipticamente como sendo em seu rosto, em sua carnalidade crua, em sua pessoa a mesma mensagem indecifrável, além de todo código. $\mathrm{O}$ 'dizer' como exposição antecipa 'o dito’ como expressão” (Dussel, 1982, p. 129).

Ora, é essa "semiótica da libertação" aqui entrevista que sofre uma reviravolta decisiva no alargamento de um debate menos "externo" e mais "endógeno" ao programa dusseliano de uma filosofia da libertação. Essa virada ganha considerável representatividade na obra do filósofo uruguaio radicado no Brasil, Sirio Lopez Velasco sob um giro de análise não só crítico, mas programaticamente propositivo que tem no "modelo argumentativo" um novo lugar ou âmbito de "interpelação ética".

\section{Interpelação ética II: Velasco e a via crítico-transcendental argumentativa}

Velasco identifica insuficiências no modelo ético precedente. Vários são os questionamentos internos por ele dirigidos a Dussel. Entretanto, não nos deteremos em cada um deles, mas concentrar-nos-emos, apenas, num pano de fundo privilegiado desse colóquio, a saber, o lugar da interpelação do Outro. Sob esse prisma, uma questão-chave, desde já, põe-se, decisivamente:

Como é possível a existência de uma relação que não afete o Outro no seu caráter de Exterioridade e que ao mesmo tempo não anule a exterioridade do polo que sendo na circunstância Totalidade, não deixa de ser, segundo a própria lógica dusseliana, o Outro do Outro? (Lopez Velasco, 1991, p. 105).

O que Velasco problematiza na empresa dusseliana é a inter-personalidade alterativa ali fundada; questão essa que se desdobra, em pelo menos, noutras três:

a) Como é possível que na relação face-a-face o Outro siga sendo mistériode-Exterioridade-incompreensível (ana-lógico)?

b) Como conceber que a Exterioridade do Outro possa ser preservada quando minha atitude de serviço para com ele supõe uma incursão minha no seu projeto?

\begin{tabular}{|c|c|c|c|c|}
\hline Rovista Dialectus & Ano 5 & n. 13 & Agosto - Dezembro 2018 & p. $100-115$ \\
\hline
\end{tabular}


c) Como compatibilizar um pensamento que define cada homem como sendo um Outro merecedor de amor-de-justiça serviçal com as exigências estratégicotáticas do projeto libertador? (Ibidem).

Como fica patente, a resposta dusseliana para a primeira pergunta, salta aos olhos. Conforme examina Velasco, a compreensão do nexo interpessoal com a exterioridade-liberdade do Outro se funda, a bem da verdade, na fé e não na razão. $O$ fator intrigante dessa posição por assim dizer "fideísta” e, portanto, “irracional” ou "transracional", é que transcende e abole um princípio racional (isto é, rigorosamente filosófico) no intuito de levar às últimas consequências o sentido último daquele nexo. É que Dussel termina por postular um princípio recalcitrante da cosmovisão metafísica medieval cujo círculo hermenêutico é, por demais, conhecido: parte-se antes do "crer" para depois “compreender". A "fé no Outro" deriva desse apelo; apelo francamente oriundo de uma tradição que, diga-se de passagem, a obra de Dussel sempre diagnosticou como sintoma de um pensamento da Totalidade. Por isso, tal cariz teológica que a sua ética libertadora assume convictamente já marca, aqui, um dos pontos de inflexão no colóquio aberto pela sua própria doutrina; colóquio esse que Velasco prolonga criticamente ao conferir estatuto a uma ética da libertação para além de toda e qualquer epifania sacral ou mística dusselianamente consentidas.

Quanto à segunda pergunta, tudo indica que Dussel não escapa ao risco de cair num “discurso tautológico do Mestre” (Lopez Velasco, 1991, p. 108). A alteridade latinoamericana é uma fonte que não se escuta no pensar alterativo. Assim,

Por outro lado, advertindo que o povo não é só o Outro exterior à Totalidade, mas também outro-como-oprimido, isto é, parte funcional da Totalidade que introjetou os valores desta, Dussel vem nos falar da tarefa que caberia ao Mestre no sentido de discernir entre o "melhor" e o "pior" das vivências populares. Para realizar-se tal tarefa nosso filósofo exige que o Mestre se dote de "um critério firme e uma teoria real e clara". O problema é que Dussel não nos proporciona nem este critério firme nem essa teoria real e clara (Lopez Velasco, 1991, p. 108109).

A crítica é bem pontual: a teoria dusseliana carece de maior substância e, portanto, clareza. Problemático aqui é a atribuição de discernimento que só o Mestre, de direito, possui: o projeto de exterioridade não deixa de ser determinado por certa instância

\begin{tabular}{|l|l|l|l|l|}
\hline Qonista Dialectus & Ano 5 & n.13 & Agosto - Dezembro 2018 & p. $100-115$ \\
\hline
\end{tabular}


totalitária $^{6}$. Ora, que lugar então é este desde onde se discerne e se critica? Quem criticaria o discernidor? A posição dusseliana nessa matéria se mostra teoricamente insatisfatória.

Agora, em relação à terceira pergunta, o projeto dusseliano revela-se, novamente, pouco convincente; e isso, sobretudo, à luz da história. Vamos lá. Dussel reconhece na revolução sandinista um exemplo paradigmático de projeto libertador. Ora, o que entra em jogo aqui é o "status do opressor e seus instrumentos", problematiza Velasco (1991, p. 110). Há uma contradição jamais enfrentada no programa dusseliano que vacila a respeito da relação libertação-violência:

$\mathrm{Na}$ sua obra assistimos sobre essa questão a um constante vai-vem da reflexão dusseliana que, ora liga a libertação à conversão e perdão do/ao opressor, ora justifica a violência defensiva do oprimido empurrado a uma guerra justa, para concluir definindo o mártir como o tipo humano por excelência (Lopez Velasco, 1991, p. 110).

De novo essa contradição interna à lógica mesma do argumento dusseliano expõe, pelo menos, duas dificuldades de princípio: a tese anterior da Alteridade digna de serviço como o poder totalitário do Mestre (ou do Mesmo) e, as contraproducentes consequências práticas à luz da experiência histórica (em regimes totalitários). Dussel parece se tornar vítima da ilusão retrospectiva de um ideal totalitário (metafísico em sua fundamentação última) que, ele próprio, alveja desde o princípio de suas críticas.

É levando em conta alguns desses déficits teóricos, internos mesmo à obra dusseliana, que Velasco busca refinar sua linha argumentativa e, com isso, avançar rumo à perspectiva de um novo paradigma ético que opere outros instrumentos, em particular, o modelo pragmático da filosofia da linguagem ordinária. A teoria austiniana dos Atos de fala (Speechs Acts) complementada por Grice (1982), p. ex., lhe parece um quadro teórico mais

\footnotetext{
${ }^{6}$ Escreve Dussel (1982, p. 100-101): “A libertação do oprimido é realizada pelo oprimido, mas por mediação da consciência crítica do mestre, condutor: o intelectual orgânico, com o povo e no povo [...]. O povo sozinho não pode libertar-se. O sistema lhe introjetou a cultura de massas, o pior do sistema. É por isso que a consciência crítica do intelectual orgânico, dos grupos críticos, das comunidades ou partidos críticos, é indispensável para que um povo assuma tal consciência”. É verdade, mais tarde, que Dussel tenta explicitar melhor essa posição, "ao dizer que a práxis de libertação não é solipsista, efetuada por um sujeito único e genial [...], mas um ato intersubjetivo, coletivo, de consenso recíproco" (Dussel, 2007, p. 119). De todo modo, o perfil gramsciano de líder intelectual é mantido como a voz de uma consciência que ainda orienta ou ilumina a práxis.
}

\begin{tabular}{|l|l|l|l|l|}
\hline Qonista Dialectus & Ano 5 & n.13 & Agosto - Dezembro 2018 & p. $100-115$ \\
\hline
\end{tabular}


adequado para pensar-aprofundar-fundar a noção de "exigência de justiça" formulada por Dussel. A questão de princípio é: por que essa exigência não é devidamente atendida nos termos mesmos da doutrina dusseliana?

A resposta de Velasco, sob esse ângulo, é clara e objetiva: "para que o interpelado se responsabilize e sirva o Outro, é preciso que antes entenda, interprete, decodifique as palavras do Outro como sendo exigências de justiça” (Lopez Velasco, 1991, p. 115). Velasco realiza um estudo crítico e pontual (1991, p. 115-123) da rede conceitual de Austin e Grice cujo inventário não adentraremos aqui. Nos limitaremos, apenas, em destacar que a devida compreensão da exigência acima posta é incompatível com uma simples profissão de fé. Antes, ela deve justificar-se racionalmente, isto é, interpelar-se no âmbito de uma interação linguística que "suponha uma 'lógica' estruturada da linguagem ordinária; lógica que, nas suas dimensões não-clássicas, tanto a teoria dos Speechs Acts como os modelos pragmáticos esforçam-se em elucidar” (Lopez Velasco, 1991, p. 123).

Parece ser de difícil defesa, à luz de uma "filosofia" que se pretende efetivamente "libertadora", cumprir a "exigência de justiça" sem levar em conta em quais condições pragmaticamente linguísticas, e, portanto, racionalmente criativas, a interpelação do Outro se reconheça enquanto tal. A validez intersubjetiva, então requerida, só adquire plena audiência mediante um processo argumentativo racional, e não conforme a hipótese pura e simples de uma empatia de crenças. Como volta a se manifestar Velasco (1991, p. 174):

[...] a ética dusseliana está enraizada num decisionismo subjetivista incapaz de argumentar, sem cair numa petição de princípio de tipo humanista (fundada por sua vez ao que parece numa petição de princípio teológica) contra um decisionismo subjetivista de signo oposto.

Ora, é preciso ir além desse subjetivismo decisório e teológico de princípio a fim de pensar um modelo ético mais profícuo que "pressupõe que todos os interlocutores se reconhecem reciprocamente como tendo os mesmos direitos à argumentação" (Lopez Velasco, 1991, p. 187) ${ }^{7}$. Uma posição como a do egoísmo ou solipsismo

\footnotetext{
${ }^{7}$ Aqui, Velasco retoma, em parte, a "ética da comunicação" proposta por Karl-Otto Apel (1994).
}

\begin{tabular}{|l|l|l|l|l|}
\hline Q Povista Dialectus & Ano 5 & n.13 & Agosto - Dezembro 2018 & p. 100 - 115 \\
\hline
\end{tabular}


produtivo/linguístico, nessas condições, contradiz, flagrantemente, o fundamento último da ética comunicacional. É nesse momento que, além da filosofia da linguagem ordinária, Velasco encontra na obra de Apel, um sugestivo argumento:

A ética da comunicação desvela diante de quem argumenta uma dialética entre uma comunidade real de comunicação (aquela da qual ele é membro mediante um processo de socialização) e uma comunidade ideal de comunicação que, por princípio, estaria em condições de compreender adequadamente o sentido dos seus argumentos e de determinar definitivamente a sua verdade. Assim, quem argumenta, pressupõe de certo modo, a comunidade ideal na comunidade real. (Lopez Velasco, 1991, p. 188).

Tal princípio apeliano parece a Velasco (1991, p. 7) um pressuposto irrevogável de toda práxis que se quer "libertadora" cujas "pretensões de validez lógico-normativas podem e devem ser argumentativamente construídas, expostas, debatidas e revisadas". É essa a essência de uma "ética argumentativa" posta numa nova agenda. Sem dúvida, não deixa de ser verdade que Dussel já havia posto em xeque certo cientificismo (ideológico) da filosofia analítica, conforme atestam tais linhas:

[...] a filosofia analítica que pretende que estudando a lógica, filosofia da linguagem, epistemologia ou filosofia da ciência, já fez tudo o que a filosofia podia pensar e assim reduzem a capacidade de reflexão filosófica a pensar entes da razão; impedem o esclarecimento da realidade prática e poética; castram a filosofia em sua possibilidade de crítica política e histórica. É necessário assumir a valiosa filosofia analítica dentro de um marco político e dialético que a abra ao amplo mundo das realidades dos oprimidos, como nações, classes e pessoas (Dussel, 1982, p. 175).

Até aqui, Velasco acompanha Dussel quanto à crítica acerca do caráter puramente sintático-semântico (ou se quiser, essencialista) que a filosofia analítica se reveste, mormente, em sua primeira expressão como tendência ou movimento. O positivismo lógico, do qual o Círculo de Viena fez escola, edita uma concepção de linguagem que em nada emancipa, em horizonte argumentativo, princípios éticos conforme vislumbra Velasco. A voz do outro e sua exigência de justiça só podem ecoar como um ato de fala feliz (no sentido austiniano) à luz de uma pragmática de agir comunicativo (sentido apeliano), mas criticamente incorporado a partir de uma ética argumentativa emancipadora (perspectiva velasquiana). Por isso, a filosofia analítica que "reduz o grito ao silêncio", para

\begin{tabular}{|l|l|l|l|l|}
\hline Q Ronista Q Dialectus & Ano 5 & n.13 & Agosto - Dezembro 2018 & p. $100-115$ \\
\hline
\end{tabular}


parafrasear Dussel (1982, p. 180), com todo o seu malabarismo lógico, é estéril em face da interpelação radical do Outro. O real problema dusseliano é que, embora tenha entrevisto esse limite do empirismo vienense, ele pouco avança, como examina Velasco, no sentido de explicitar em quais condições o apelo de justiça do Outro é um clamor, de jure et de facto, intersubjetivamente válido. A estratégia metodológica velasquiana se reorienta, radicalmente, a partir desse questionamento imprescindível. É preciso perguntar, antes de tudo, pelas condições pragmáticas e consensuais nas quais a exigência de justiça não é um mero flatus vocis, isto é, uma pálida interpellatio de um subjetivismo espontaneísta.

O melhor encaminhamento dessa crítica é o que, na linha perseguida por Velasco, reconfigura o conceito de libertação noutra chave de leitura. Para tanto, em seu programa de uma ética argumentativa, ele deduz com o operador de "condicional" da gramática profunda da pergunta que instaura a ética, "Que devo fazer?", três normas fundamentais. (Lopez Velasco Lopez Velasco, 2003; 2005). Em síntese, a primeira norma obriga zelar por nossa liberdade individual de decidir; a segunda preceitua realizar consensualmente essa liberdade e a terceira obriga zelar pela saúde da natureza humana e não humana, preservando-a e regenerando-a. A decisão individual livre, a liberdade realizada pelo consenso e o zelo da natureza humana e não humana vislumbram, como normas essenciais, outro horizonte possível da libertação. É o que formula Velasco (1999, p. 45):

Sobre a base das três normas da Ética defino a Libertação como um processo histórico de construção da liberdade consensual de decisão acerca de nossas vidas, através da discussão e da luta contra as instâncias de dominação intersubjetiva e auto-repressão alienada; processo do qual faz parte o estabelecimento de relações produtivas e estéticas de caráter preservadorregenerador entre os seres humanos e o restante da Natureza.

É nessa perspectiva mais ampla das três normas éticas em foco, segundo tal modelo argumentativo, que a tese da libertação pode realinhar-se programaticamente. Como vemos, o termo "libertação" assume outro acento sem perder, é claro, seu brio ético como exigência fundamentalmente indispensável. O que se propõe de novo? O princípio de uma ética argumentativa fundada no consenso, levando em conta, sobretudo, a inexistência de qualquer contraposição entre consenso e dissenso o que redundaria nos termos de Austin

\begin{tabular}{|l|l|l|l|l|}
\hline Q Ronista Q Dialectus & Ano 5 & n.13 & Agosto - Dezembro 2018 & p. $100-115$ \\
\hline
\end{tabular}


(1990), numa flagrante "contradição performativa" 8 . Ora, trata-se aqui de dois princípios que "estão em uma relação dialética onde um se transforma no outro" (Lopez Velasco, 1999, p. 44).

Isso posto, um processo de libertação real e, de passagem, concreto, será aquele que, efetivamente, seja capaz de acompanhar esse movimento dialético, assumindo a dimensão profunda dessa relação que é a alma mesma da argumentação e da práxis. A libertação só será uma transformação real se não separar-se da história como processo; processo esse sempre aberto e plural e, em tal medida, intersubjetivo no intuito de uma emancipação do outro como outro. Sob esse prisma, a relação com a Natureza se mostra, prioritariamente, segundo a clássica tese de Marx, como uma relação dialética. Não há como pensar o homem e a alteridade fora dessa relação. O migrante que é separado de sua terra e de sua gente, se desumaniza justamente porque a Natureza fora desprovida do princípio de preservação-regeneração ético e dialeticamente requerido, mas também conforme pontua Velasco, porque as duas primeiras normas da ética não são satisfeitas, a da liberdade de decisão individual e a do consenso argumentativamente requerido. Ora, é

\footnotetext{
${ }^{8}$ Esse controvertido tema é aprofundado por Velasco a partir de uma fina análise crítica do pensamento pósmoderno de Lyotard (1979) que parece confundir dissenso e consenso. Ora, essa confusão ou simples oposição conceitual "mais parece ser uma 'contradição performativa' ou 'contradição ilocucionária' no sentido de Austin, na medida em que o conteúdo ilocucionário do ato linguístico se contrapõe à força ilocucionária veiculada pelo mesmo" (Lopez Velasco, 2005, p. 18). Chega a ser curioso, nota Velasco (2005, p. 247), que "Lyotard quer criar consenso acerca da importância do dissenso, mas se engana (de fato contradiz o que faz em seu livro) ao acreditar que a atitude da época (pós-moderna) refletida em seu livro, representa a superação do consenso pelo dissenso". Nisso, cabe advertir: "todo consenso é sempre provisório. As normas da ética são históricas, e a história está sempre aberta” (Idem, op. cit., p. 19). Ora, é esse elogio ao dissenso que, depois de Lyotard, volta à cena, novamente com Rancière que associa o princípio do consenso tanto à noção de democracia em sua versão liberal quanto a um certo marxismo especulativo supostamente pretendido pela teoria da razão comunicativa de Habermas. Na contramão de ambas as tendências, predica Rancière (1996, p. 374): "É preciso que se instaure uma cena de conflito. E essa cena não é apenas a oposição de dois grupos, é a reunião conflituosa de dois mundos sensíveis: o mundo em que os plebeus não falam e o mundo em que falam. É isso o que chamo dissenso: não um conflito de pontos de vista nem mesmo um conflito pelo reconhecimento, mas um conflito sobre a constituição mesma do mundo comum, sobre o que nele se vê e se ouve, sobre os títulos dos que nele falam para ser ouvidos e sobre a visibilidade dos objetos que nele são designados. $O$ dissenso não é a guerra de todos contra todos. Ele dá ensejo a situações de conflito ordenadas, a situações de discussão e de argumentação". Essa matéria vai longe, da qual Dussel (2007, p. 26-27) também não se evade. Este quer pensar o consenso num horizonte que transcende a modernidade, isto é, numa "civilização trans-capitalista, trans-moderna e não pós-moderna que ainda é moderna, eurocêntrica, metropolitana" (Dussel, 2007, p. 94). De todo modo, para o leitor interessado, fica a sugestão de uma discussão mais pormenorizada tanto da versão liberal da democracia quanto da teoria da ação comunicativa de Habermas, além, é claro, de Lyotard, levadas a cabo por Lopez Velasco (2005, p. 238-249; 2017b).
}

\begin{tabular}{|l|l|l|l|l|}
\hline Q Rovista Dialectus & Ano 5 & n.13 & Agosto - Dezembro 2018 & p. $100-115$ \\
\hline
\end{tabular}


nessa mesma trilha que Velasco elabora sua proposta sob o conceito de "ecomunitarismo" cujo delineamento é assim formulado:

Chamo "Ecomunitarismo" a ordem social utópica pós-capitalista (talvez nunca alcançável, mas indispensável horizonte histórico guia da ação) capaz de se articular com base nas três normas da Ética e de manter-se pela postura de seres humanos em atitude de libertação (Lopez Velasco, 1999, p. 45) ${ }^{9}$.

O "ecomunitarismo" uma vez proposto nesses termos, ressignifica substancialmente o lugar da interpelação ética a partir de sua dimensão linguisticamente pragmática. Trata-se, a bem da verdade, de outra semiótica da libertação como paradigma ético alternativo vislumbrado sempre na direção de um horizonte pós-capitalista como utopia orientadora da práxis.

É, pois, nessa perspectiva que a obra de Velasco, ainda em curso, se torna expressão emblemática de um movimento reflexivo que, em ritmo latino-americano, reabre uma agenda permanente de colóquio.

\section{Conclusão}

À guisa de conclusão, vimos que, para Dussel, o rosto do pobre, além de sua feição desfigurada pela lógica do capital, se expressa também como um rosto sagrado, cujo reconhecimento se dá, antes de tudo, por um ato de fé. Sua natureza não é só heroica (Che Guevara), mas soteriológica, profética (Dom Oscar Romero). É aí que se infunde a interpelação ética tout court como lugar privilegiado de enunciação.

Já Velasco edita outra interface de agenda. Sua perspectiva alia até certo ponto o programa dusseliano naquilo em que este é capaz de problematizar, qual seja, o ideal de libertação tão necessário quanto premente. No entanto, Velasco se afasta do caráter

\footnotetext{
9 Aqui, cabe precisar, ao menos, um importante conceito haurido por Velasco, a noção de utopia. Ele esclarece: "O ecomunitarismo é hoje uma 'utopia', haja vista que, no capitalismo, 'não está em nenhum lugar' (é, literalmente, ouk - topos). Saber se algum dia poderá ocupar um lugar com as características genéricas antes descritas é uma questão que somente a ação humana poderá resolver. É bom que se diga de imediato que, ainda que isso seja discutível, o que vale a partir das normas éticas transcendentalmente deduzidas é o caminho histórico que aponta para o ecomunitarismo, que não é outra coisa senão o processo histórico de libertação" (Lopez Velasco, 2005, p. 194-195).
}

\begin{tabular}{|c|c|c|c|c|}
\hline Qevista Dialectus & Ano 5 & n. 13 & Agosto - Dezembro 2018 & p. $100-115$ \\
\hline
\end{tabular}


subjetivista, humanista ou mesmo místico que esse ideal pode sugerir. Por isso, ele reclama outro lugar em que a interpelação ética se instale de maneira mais crítica e propositiva. Trata-se, agora, de reconhecer o rosto do Outro via uma ética comunicacional na qual interpelante e interpelado estejam em condições mais equânimes de discurso tendo como princípio regulador o consenso; ética essa pautada nas três normas fundamentais rumo ao ecomunitarismo como perspectiva utópica. O que o filósofo põe em debate é uma nova ordem socioambiental pós-capitalista que também promova, para além de sua versão liberal burguesa, outra alternativa democrática de inspiração socialista em pleno século XXI (Lopez Velasco, 2017a; 2017b) ${ }^{10}$.

Em suma, é esse capítulo que ora se inscreve na história presente num raio de abrangência mais amplo e complexo das relações sociais, culturais e econômicas. Trata-se de uma reflexão jamais evasiva, mas engajada concretamente. Ela nos convida a tomar parte no desafio constante de repensar o lugar desde onde interpelamos.

\section{Bibliografia}

APEL, K-O. Estudos de moral moderna. Tradução de Benno Dischinger. Petrópolis, RJ: Vozes, 1994.

AUSTIN, J. L. Quando dizer é fazer: palavras e ação. Tradução de Danilo Marcondes de Souza Filho. Porto Alegre: Artes Médicas, 1990.

DUSSEL, E. D. Filosofia da libertação na América Latina. Trad. Luiz João Gaio. São Paulo/Piracicaba, SP: Loyola/Unimep, 1982 (Coleção Reflexão Latino-Americana, 3, I).

. Ética comunitária. Tradução de Jaime Clasen. 2. ed. Petrópolis, RJ: Vozes, 1987. (Série III: A libertação na história; vol. 8).

. 20 teses de política. Tradução de Rodrigo Rodrigues. São Paulo: Expressão Popular, 2007.

${ }^{10}$ Como vimos, o contexto ecomunitarista põe em xeque o ideal "humanista", resquício de certa concepção democrática, ainda alimentada na ótica dusseliana. Aqui, não apenas, a figura do líder revolucionário, mas do mártir (profeta) e até mesmo do líder carismático é que se visa criticamente como expressão de certo personalismo mistificador não raras vezes revestido por atores políticos de "esquerda". Para o ecomunitarismo, "não há espaço para que refloresça o culto à personalidade (autoridade) nem para que se mantenha a tentação da reeleição indefinida que hoje afeta inclusive dirigentes que dizem optar pelo 'socialismo do século XXI"” (Lopez Velasco, 2017b, p. 130).

\begin{tabular}{|l|l|l|l|l|}
\hline Q Povista Dialectus & Ano 5 & n.13 & Agosto - Dezembro 2018 & p. 100 - 115 \\
\hline
\end{tabular}


GRICE, H. P. Lógica e conversação. In: DASCAL, Marcelo (Org.). Pragmática: problemas, críticas, perspectivas da linguística. Tradução de João Vanderley Geraldi. Campinas, SP: Editora Unicamp, 1982.

LEVINAS, E. Totalité et infini: essai sur l'extériorité. 10. ed. Paris: Kluwer Academic, 2006.

LOPEZ VELASCO, S. Reflexões sobre a filosofia da libertação. Campo Grande: CEFIL, 1991.

. Etica de la liberación. Rio Grande, RS: Edgraf, 2000.

. Fundamentos lógico-linguísticos da ética argumentativa. São Leopoldo, RS: Nova Harmonia, 2003.

. Ética para o século XXI: rumo ao ecomunitarismo. São Leopoldo, RS: Editora Unisinos, 2005.

Ideias para o socialismo do século XXI com visão marxiana-ecomunitarista. Rio Grande: Ed. FURG, 2012.

FI, 2017a.

. Ideas y experiencias de la democracia: una mirada ecomunitarista. Porto Alegre:

. Contribuição à teoria da democracia: uma perspectiva ecomunitarista. Porto Alegre: FI, $2017 \mathrm{~b}$.

LYOTARD, J-F. La condition postmoderne: rapport sur le savoir. Paris: Minuit, 1979.

RANCIÈRE, J. “O dissenso". In: NOVAES, Adauto (Org.). A crise da razão. Tradução de Paulo Neves. São Paulo: Companhia das Letras, 1996, p. 367-382. 